\title{
Burkholderia cepacia: a rare cause of bacterial keratitis
}

\author{
Mohtar Ibrahim, ${ }^{1}$ Jin Yi Yap ${ }^{1,2}$
}

Department of Ophthalmology, Universiti Sains Malaysia School of Medical Sciences, Kubang Kerian, Kelantan, Malaysia ${ }^{2}$ Surgical Department, Universiti Malaysia Sabah, Kota Kinabalu, Sabah, Malaysia

\section{Correspondence to} Professor Mohtar Ibrahim, mohtar@usm.my

Accepted 12 April 2018

\section{SUMMARY}

We describe the first clinical case of Burkholderia cepacia keratitis registered in Southeast Asia. A man in his mid-70s with underlying poorly controlled diabetes mellitus came with complaints of painful red left eye for 4 days. This was accompanied with photophobia and blurring of vision after being injured by a wooden particle while cutting grass. Slit-lamp examination showed a paracentral anterior corneal stromal infiltrates with overlying epithelial defect. Culture of the corneal smear isolated $B$. cepacia that was sensitive to ceftazidime, meropenem and bactrim (trimethorprim and sulfomethoxazole). Topical ceftazidime was given intensively to the patient and the infection resolved after 6 weeks of treatment.

\section{BACKGROUND}

Burkholderia cepacia infection is a rare cause of bacterial keratitis. The case we are reporting is one of the first clinical cases of corneal ulcer in Southeast Asia caused by Burkholderia infection.

\section{CASE PRESENTATION}

A man in his mid-70s with underlying poorly controlled type 2 diabetes mellitus presented with a sudden onset of painful red left eye for a duration of 4 days and was accompanied with purulent discharge together with photophobia and blurring of vision. The symptoms started after the patient encountered a wooden particle entering his left eye while cutting grass.

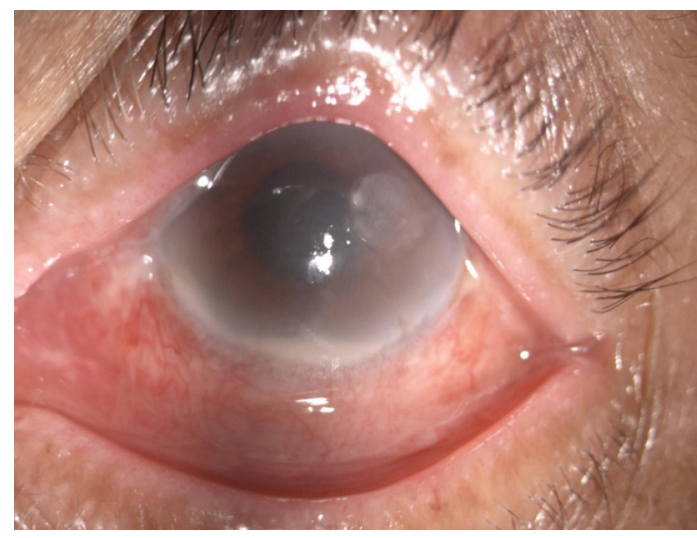

Figure 1 Demonstrating paracentral infiltrates with injected conjunctiva. A streak of hypopyon was noted at the bottom of anterior chamber.

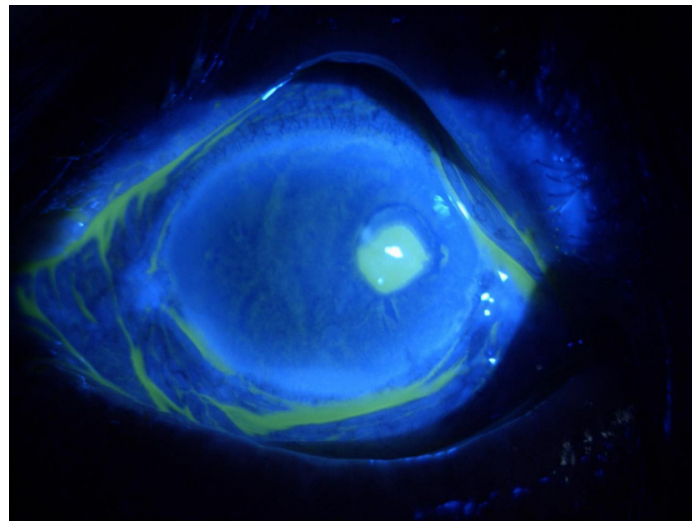

Figure 2 Demonstrating overlying epithelial defect of the keratitis.

On examination, the left eye best corrected visual acuity (BCVA) was 20/150 and 20/20 for the right eye. Slit-lamp biomicroscopy examination showed hyperaemic conjunctiva with paracentral anterior corneal stromal infiltrates; measuring $2 \mathrm{~mm} \times 2.5 \mathrm{~mm}$ at 3 o'clock (figure 1). The margin was ill-defined and fluorescein staining test showed an overlying epithelial defect (figure 2). The surrounding cornea was oedematous due to inflammation. The anterior chamber inflammatory activity was $3+$ with the presence of hypopyon and the intraocular pressure was $24 \mathrm{~mm} \mathrm{Hg}$. Posterior segment examination was normal. The right eye anterior and posterior segment examination was normal.

\section{INVESTIGATIONS}

Corneal scrapings were sent for grams staining, giemsa staining and microbiological cultures. The corneal scraping samples were inoculated on blood agar, chocolate agar, Sabouraud dextrose agar and MacConkey agar. Gram-negative bacilli were detected on grams staining. Cultures of the corneal smear showed prominent pure growth of shiny, colourless, gram-negative bacilli on blood agar and MacConkey culture plate. However, since there was no growth on the Sabouraud dextrose agar, thus fungal infection was ruled out. The isolate was subsequently tested using biochemical tests including triple sugar iron, indole, citrase, urase, methyl red, catalase, coagulase and colistin. The organism was then sent for final identification using VITEK 2 system. The isolated organism was confirmed to be $B$. cepacia and sensitive to ceftazidime, meropenem and bactrim (trimethorprim and 


\begin{tabular}{|c|c|c|c|c|}
\hline Author/year/article type & Age/gender/region & Predisposing factor & Disease & Visual/clinical outcome \\
\hline $\begin{array}{l}\text { Pathengay et al/2005\% } \\
\text { case report }\end{array}$ & 53/male/India & $\begin{array}{l}\text { Uncomplicated cataract surgery with } \\
\text { postoperative endophthalmitis }\end{array}$ & Recurrent endophthalmitis & $\begin{array}{l}\text { Phthisical eye } \\
\text { No light perception }\end{array}$ \\
\hline \multirow[t]{2}{*}{$\begin{array}{l}\text { Eser et al/2006 I } \\
\text { case report }\end{array}$} & 63/male/Turkey & $\begin{array}{l}\text { Diabetes mellitus and uncomplicated cataract } \\
\text { surgery }\end{array}$ & Endophthalmitis & $20 / 63$ \\
\hline & 72/Male/Turkey & Uncomplicated cataract surgery & Endophthalmitis & $20 / 50$ \\
\hline $\begin{array}{l}\text { Ying-Cheng et al/2006 }{ }^{7} \text {, } \\
\text { case report }\end{array}$ & 16/female/Taiwan & $\begin{array}{l}\text { Underwent orthokeratology Contact lenses } \\
\text { fitting }\end{array}$ & Keratitis & $20 / 20$ \\
\hline $\begin{array}{l}\text { Ornek et al/2009 }{ }^{8} \text {, } \\
\text { case report }\end{array}$ & 75/female/Turkey & Complicated cataract surgery & Endophthalmitis & Loss to follow-up \\
\hline \multirow[t]{4}{*}{$\begin{array}{l}\text { Chaurasia et al/2011 } / \\
\text { case series }\end{array}$} & Not stated/India & $\begin{array}{l}\text { Pterygium surgery } \\
\text { Topical steroid eye drops }\end{array}$ & Keratitis & Corneal scar* \\
\hline & Not stated/India & Chicken pox infection & Keratitis & Corneal scar* \\
\hline & Not stated/India & Trauma with stone & Keratitis & $\begin{array}{l}\text { Clear } \\
\text { graft* }^{*}\end{array}$ \\
\hline & Not stated/India & $\begin{array}{l}\text { Postpenetrating keratoplasty with topical } \\
\text { steroid eye drops }\end{array}$ & Keratitis & Corneal scar* \\
\hline Reddy et al/2013 10 case report & 27/male/India & LASIK & Keratitis & $20 / 20$ \\
\hline
\end{tabular}

*Visual outcome of the case series was not mentioned in the study.

LASIK, laser-assisted in situ keratomileusis.

sulfomethoxazole) and resistant to chloramphenicol, colistin and gentamicin.

\section{DIFFERENTIAL DIAGNOSIS}

Bacterial keratitis is commonly caused by gram-positive bacteria. A clinical review showed that out of 306 cases of bacterial keratitis, $65.2 \%$ were caused by gram-positive cocci. There were only about $16.4 \%$ of cases were due to gram-negative bacilli. ${ }^{1}$ Among all the gram-negative bacilli, Pseudomonas aeruginosa top the list of the causative agents. ${ }^{1}$ Clinically, it would be difficult to differentiate the causative agent of the bacterial keratitis as both gram-negative and gram-positive organisms can have rapid onset, predominance of central (23\%) and inferior (nasal 24\% and temporal 22\%) infiltrates, presence of anterior chamber inflammation and the visual acuity can widely vary. ${ }^{1}$ All these features were seen in the case we presented.

Our initial diagnosis was $P$. aeruginosa bacterial keratitis based on the immediate gram staining result which showed gram-negative bacilli. However, the corneal scraping culture, biochemical tests and VITEK 2 organism identification system confirmed the organism as B.cepacia. The treatment changes were made based on the sensitivity result.

\section{TREATMENT}

The patient was initially started on topical ceftazidime 5\% and topical moxifloxacin $0.5 \%$ half hourly instillation. Topical ceftazidime 5\% was prescribed initially to empirically cover for $P$. aeruginosa, the the most common organism that causes bacterial keratitis at our centre. ${ }^{2}$ Topical moxifloxacin, a broad-spectrum antibiotic, was used to cover other gram-positive organism. Topical homatropine $2 \%$ and preservative free artificial tears drops were initiated as well for pain relief and to prevent formation of synechiae. On receiving the cultures and sensitivity results, the patient was subsequently treated intensively with topical ceftazidime and his symptoms improved dramatically within 1 week. The stromal infiltrates reduced greatly in size. There was regression of conjunctival hyperaemia and anterior chamber inflammatory activity with signs of corneal re-epithelisation. The diameter of stromal infiltrates also reduced.

\section{OUTCOME AND FOLLOW-UP}

During subsequent follow-up, the epithelial defect fully re-epithelised with resolution of the corneal oedema and corneal infiltrates, leaving behind a faint nebulous scar. Topical antibiotics were tapered down with clinical resolution of his keratitis. Topical dexamethasone $0.1 \%$ four times a day was added later to assist in reduction of scars formation. Unfortunately, after 6 weeks of treatment, his visual acuity improved to only 20/70 as there was a residual corneal scar near the visual axis. The reduced best corrected vision was contributed by the presence of dense corneal scar. Alternatively, further treatment with optical penetrating keratoplasty for a better visual outcome was offered but was declined by the patient.

\section{DISCUSSION}

B. cepacia, previously known as Pseudomonas cepacia, is one out of 17 species of the B. cepacia complex. The species was first discovered in the 1950s by Walter Hagemeyer Burkholder, an American plant pathologist, who observed that the organism had caused the soft rot of onion skin. Only in the early 1990s, the taxonomic reappraisal regrouped the RNA group II pseudomonads to a new genus, Burkholderia, and B. cepacia as one of these species. ${ }^{3}$ It is a gram-negative, non-spore forming, non-fermentative, motile, aerobic bacillus, and it is catalase and oxidative positive. The optimal temperature for the B. cepacia to grow is at $30^{\circ} \mathrm{C}-35^{\circ} \mathrm{C}$. It is commonly found in plants, animals, water, soils and also as human pathogens. ${ }^{34}$

The organism was labelled as non-pathogen until early 1980 s as it emerged as one of the opportunistic pathogen. ${ }^{3}$ Initially it was only found to be due to contact with contaminated disinfectant and anaesthetic solution. However, later on it became an emerging nosocomial infection in the USA. ${ }^{3} \mathrm{~B}$. cepacia infection is mainly found in patients with cystic fibrosis, a genetic disease that causes persistent lung infections. Fatal cases reported in early 1990s were due to severe B. cepacia pneumonia and septicaemia. Other than that, B. cepacia can also be implicated in urinary tract infection and endocarditis.

$B$. cepacia is an opportunistic pathogen that may implicate a wide array of diseases. The systemic Burkholderia infection can 


\begin{tabular}{|c|c|c|c|c|}
\hline No & Cephalosphorins & Chloramphenicol & Quinolones & Aminoglycosides \\
\hline 1 & $S$ & $\mathrm{R}$ & $S$ & $\mathrm{R}$ \\
\hline 2 & $S$ & - & $S$ & $\mathrm{R}$ \\
\hline 3 & $S$ & - & $S$ & $\mathrm{R}$ \\
\hline 4 & $S$ & - & $S$ & $\mathrm{R}$ \\
\hline 5 & $S$ & - & $S$ & $\mathrm{R}$ \\
\hline 6 & $S$ & $S$ & $S$ & $\mathrm{~S}$ \\
\hline 7 & $S$ & $\mathrm{R}$ & $S$ & $S$ \\
\hline 8 & $S$ & $\mathrm{R}$ & $\mathrm{R}$ & $\mathrm{R}$ \\
\hline 9 & $S$ & $\mathrm{R}$ & $\mathrm{R}$ & $\mathrm{R}$ \\
\hline 10 & $\mathrm{R}$ & - & $\mathrm{R}$ & $\mathrm{R}$ \\
\hline 11 & $S$ & $\mathrm{R}$ & - & $\mathrm{R}$ \\
\hline
\end{tabular}

Number of patient arranged chronologically as in the sequences of table 1 . $\mathrm{R}$ denotes resistance and $\mathrm{S}$ denotes sensitive.

No 11 is the antibiotic sensitivity pattern for the case that we are reporting.

be severe or even fatal. In terms of Burkholderia spp-related ocular infection, the incidence rate is relatively lesser. Table 1 lists the five case reports and one case series that has been reported for the Burkholderia spp-related ocular infection. ${ }^{5-10}$ From the table we can observe that there were six reported cases from India, two cases from Turkey and one from Taiwan. This will be the first reported case in the region of Southeast Asia. There were no gender predilection or specific age group for the disease as well.

There are various virulence factors that can assist the organism in the infection of host cells. These include the presence of specific glycolipid and glycoprotein receptors on the organism surface, ability of the intracellular invasion and in vivo survival, secretion of lipases, proteinase, metalloproteinases and also exotoxin. ${ }^{11}$ Similar to the cases reported, the presence of underlying factor, breaking the integrity of the eye, such as trauma and intraocular surgery, would have resulted in higher risk of Burkholderia ocular infection. Another noticeable predisposing factor is the host immunity status which is seen in our patient who had underlying poorly controlled diabetes mellitus that may have weakened his immune system and thus, predisposed him to the infection.

Table 2 showing the antibiotic sensitivity of all the cases reported. From the table we found that Burkholderia spp was resistant to most of the common antibiotics we use in daily clinical practice. It is due to the following mechanism: presence of various efflux pumps that remove the antibiotics from the bacteria, presence of biofilm and changes in the cell envelope that will reduce the membrane permeability to antibiotics. These protective mechanisms of the organism cause multiple-drug resistance including aminoglycosides, quinolones, polymyxins and $\beta$-lactams. ${ }^{4}$ Our patient was fortunate as the organism was still sensitive to ceftazidime, the third-generation cephalosporins, and he responded well to the treatment.
Learning points

- Recognising the clinical features of Burkholderia ocular infection which can mimic the features of other common organism that causes bacterial keratitis.

- Understanding about the characteristics and virulence factors of this rare organism.

- Taking note on the high antibiotic resistance of this organism as inappropriate antibiotics use can result in treatment failure.

Contributors Ml: was the main physician in charged of the patient we reported; planned and designed the write up of this case report; provided important intellectual content for the discussion of the write up; and finalized the case report before the submission. JYY: was in charged of the write up of the case presentation and data collection including the consent taking and obtaining the images; involved in the literature review of the case report as well; and designed the tables for the literature review.

Funding The authors have not declared a specific grant for this research from any funding agency in the public, commercial or not-for-profit sectors.

Competing interests None declared.

Patient consent Obtained.

Provenance and peer review Not commissioned; externally peer reviewed.

(c) BMJ Publishing Group Ltd (unless otherwise stated in the text of the article) 2018. All rights reserved. No commercial use is permitted unless otherwise expressly granted.

\section{REFERENCES}

1 Bourcier T, Thomas F, Borderie V, et al. Bacterial keratitis: predisposing factors, clinical and microbiological review of 300 cases. Br J Ophthalmol 2003;87:834-8.

2 Norina TJ, Raihan S, Bakiah S, et al. Microbial keratitis: aetiological diagnosis and clinical features in patients admitted to Hospital Universiti Sains Malaysia. Singapore Med J 2008;49:67-71.

3 Govan JR, Hughes JE, Vandamme P. Burkholderia cepacia: medical, taxonomic and ecological issues. J Med Microbiol 1996;45:395-407.

4 Sousa SA, Ramos CG, Leitão JH. Burkholderia cepacia complex: emerging multihost pathogens equipped with a wide range of virulence factors and determinants. Int J Microbiol 2011;2011:1-9.

5 Pathengay A, Raju B, Sharma S, et al. Recurrent endophthalmitis caused by Burkholderia cepacia. Eye 2005;19:358-9.

6 Eser I, Altan T, Stahl JE, et al. Two cases of Burkholderia cepacia endophthalmitis. Br J Ophthalmol 2006;90:1211.

7 Ying-Cheng L, Chao-Kung L, Ko-Hua C, et al. Daytime orthokeratology associated with infectious keratitis by multiple gram-negative bacilli: Burkholderia cepacia, Pseudomonas putida, and Pseudomonas aeruginosa. Eye Contact Lens 2006;32:19-20.

8 Ornek K, Ozdemir M, Ergin A. Burkholderia cepacia keratitis with endophthalmitis. J Med Microbiol 2009;58:1517-8.

9 Chaurasia S, Muralidhar R, Das S, et al. Keratitis caused by Burkholderia cepacia. Br J Ophthalmol 2011;95:746-7.

10 Reddy JC, Tibbetts MD, Hammersmith KM, et al. Successful management of Burkholderia cepacia keratitis after LASIK. J Refract Surg 2013;29:8-9.

11 McClean S, Callaghan M. Burkholderia cepacia complex: epithelial cell-pathogen confrontations and potential for therapeutic intervention. J Med Microbiol 2009;58:1-12. 
Rare disease

Copyright 2018 BMJ Publishing Group. All rights reserved. For permission to reuse any of this content visit http://group.bmj.com/group/rights-licensing/permissions.

BMJ Case Report Fellows may re-use this article for personal use and teaching without any further permission.

Become a Fellow of BMJ Case Reports today and you can:

- Submit as many cases as you like

- Enjoy fast sympathetic peer review and rapid publication of accepted articles

- Access all the published articles

- Re-use any of the published material for personal use and teaching without further permission

For information on Institutional Fellowships contact consortiasales@bmjgroup.com

Visit casereports.bmj.com for more articles like this and to become a Fellow 